Global Conferences Series:

Social Sciences, Education and Humanities (GCSSSEH), Volume 6, 2020

International Conference Fakultas Tarbiyah dan Keguruan Universitas Islam Negeri Imam Bonjol Padang (ICFTKUINIBP) 2020

DOI: https://doi.org/10.32698/icftk395

\title{
The National Curriculum in Development in the Reform Period
}

\section{Kurikulum Nasional dalam Perkembangan pada Periode Reformasi}

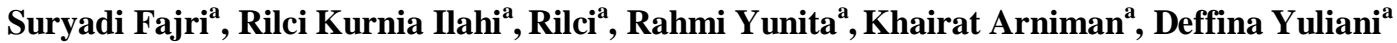 \\ ${ }^{a}$ Universitas Islam Imam Bonjol, Padang, Indonesia \\ E-mail: suryadifajri@uinib.ac.id
}

\begin{abstract}
This artikel is titled "National Curriculum In Its Development During the Reform period". The main problem in writing this thesis is (1) Curriculum development in 2004 (KBK), (2) Curriculum development in 2006 (KTSP), (3) Curriculum development in 2013. The purpose of this study is to analyze the development of the curriculum in 2004 (KBK), analyze the development of the curriculum in 2006 (KTSP), analyze the development of the curriculum in 2013. To achieve the above objectives, the study was conducted using Library research using measures: The collection of data sources in this study is a printed material that can provide information about the National Curriculum in the Development of the Reform Period, primary sources are the results of research or the writings of researchers such as books: Mulyasa, curriculum level of the Unit of Education, while secondary sources are books relevant to the title of this thesis. Data collection is done with literature studies, document studies, accessing the internet. Data analysis is done by content analysis techniques and inductive methods, then described scientifically so as to produce scientific works of form (thesis) that can be accounted for scientifically. From the results of the study found that learning in kbk if viewed special characteristics that the learning system in kbk is very practical for the development of students, in the sense that this system is universal in nature that has covered the overall learning activities that become the basic needs of students. but it does not close the possibility that students need intensive direction and coaching of teachers, in order to achieve professional educational goals. In addition, the characteristics of the Education Unit Level Curriculum is an individual development-oriented curriculum, which can be seen from the basic competency standards outlined by the indicators. In ktsp there is a component of self-development that emphasizes on the aspects of talent development and student interest. From competency-based curriculum 2004, Education Unit Level Curriculum 2006, and Curriculum-13 obtained that k-13 is more efficient to improve the quality of learning learning students. However, Curriculum 13 is an improvement in the effectiveness of learning in the education unit and the addition of learning time in schools. K-13 students are looking to find out using current technology.
\end{abstract}

Keywords: Curriculum, development, reform

\section{PENDAHULUAN}

Secara etimologi istilah kurikulum (curriculum) berasal dari bahasa Yunani, yaitu curir yang artinya "pelari" dan curere yang berarti "tempat berpacuh". Istilah kurikulum berasal dari dunia olah raga, terutama dalam bidang atletik pada zaman Romawi Kuno di Yunani. Dalam bahasa Prancis, istilah kurikulum berasal dari kata courier yang berarti berlari (to run). Menurut UU Nomor 20 Tahun 2013 tentang, sistim pendidikan Nasional dikatakan bahwa kurikulum adalah seperangkat rencana dan peraturan mengenai isi dan bahan pelajaran serta cara yang digunakan sebagai pedoman menyelenggarakan kegiatan belajar mengajar. Adapun kurikulum menurut para ahli :

a. Menurut Arifin Kurikulum adalah seluruh bahan pelajaran yang harus disajikan dalam proses kependidikan dalam suatu sistem internasional pendidikan.

b. Darajat melihat kurikulum sebagai suatu program yang direncanakan dalam bidang pendidikan dan dilaksanakan untuk mencapai sejumlah tujuan-tujuan pendidikan tertentu (Sanjaya, 2008).

Kurikulum merupakan inti dari proses pendidikan. Kurikulum merupakan bidang yang paling langsung berpengaruh terhadap hasil pendidikan. Kurikulum sangat menentukan proses dan hasil suatu sistem pendidikan. Perubahan kurikulum sering dipengaruhi oleh faktor politik (Muhammedi, 2016). 
"Soetopo dan Soemanto (1991: 38) menyatakan bahwa suatu kurikulum disebut mengalami perubahan bila terdapat adanya perbedaan dalam satu atau lebih komponen kurikulum antara dua periode tertentu, yang disebabkan oleh adanya usaha yang disengaja."

Perubahan kurikulum mengenai tujuan maupun alat-alat atau cara-cara untuk mencapai tujuan itu. Mengubah kurikulum sering berarti turut mengubah manusia, yaitu guru, pembina pendidikan, dan merekamereka yang mengasuh pendidikan. Itu sebab perubahan kurikulum dianggap sebagai perubahan sosial, suatu social change (Soemanto \& Soetopo, 1991).

Pengembangan kurikulum adalah suatu proses yang kompleks, dan melibatkan berbagai komponen, yang tidak hanya menuntut keterampilan teknis, dari pihak pengembangan terhadap pengembangan berbagai komponen kurikulum, tetapi harus pula dipahami berbagai faktor yang mempengaruhinya. Pengembangan kurikulum secara vertikal berkaitan dengan kontinuitas antara berbagai jenjang pendidikan (pendidikan dasar, menengah, dan pendidikan tinggi).

Munculnya peraturan perundang-undangan yang baru telah membawa implikasi terhadap paradigma baru dalam proses pengembangan kurikulum. Kondisi masa sekarang dan kecenderungan yang akan terjadi pada masa yang akan datang memerlukan persiapan dari generasi muda dan peserta didik yang memiliki kompetensi multidimensional. Mengacu pada hal-hal tersebut, pengembangan kurikulum harus mampu mengantisipasi segala persoalan yang dihadapi masa sekarang dan masa yang akan datang.

Seiring berjalannya waktu jika dilihat dari sejarahnya, bahwa kurikulum selalu mengalami perubahan dan mengalami pembaharuan dari kurikulum yang sebelumnya. Kurikulum dalam dunia pendidikan ini yang bukan hanya di Indonesia, tetapi berbagai Negara, bahwa perubahan kurikulum tersebut dapat dilihat dari filosofinya, sosialnya, psikologi dan hakikat dari pengetahuan yang dimiliki oleh pengembangan kurikulum.

Kurikulum Berbasis Kompetensi (KBK) merupakan suatu perkembangan yang terjadi sebagai dampak dari perkembangan era reformasi, dimana KBK ini merupakan suatu konsep, pendekatan, strategi kurikulum yang menekankan pada penguasaan berbagai kompetensi (Arifin, 2011). Tujuan utama kurikulum ini adalah memandirikan atau memberdayakan sekolah dalam mengembangkan kompetensi yang akan disampaikan kepada peserta didik, sesuai dengan kondisi lingkungan. Sedang Kurikulum Tingkat Satuan pendidikan (KTSP) atau kurikulum 2006 termasuk salah satu wujud reformasi pendidikan yang memberikan otonomi kepada sekolah dan satuan pendidikan untuk mengembangankan kurikulum sesuai dengan potensi, dan tuntutan. KTSP adalah kurikulum operasional yang disusun oleh dan dilaksanakan di masing-masing satuan pendidikan (Hakim, 2014). Dan kurikulum 2013 adalah kurikulum yang berlaku di Indonesia. Kurikulum ini merupakan kurikulum yang diterapkan pemerintah sebagai penganti kurikulum 2006, dan kurikulum 2013 ini merupakan kurikulum uji coba pada beberapa sekolah.

Perubahan kurikulum didasari pada kesadaran bahwa perkembangan dan perubahan yang terajadi dalam kehidupan beramasyarakat, berbangsa dan bernegara di Indonesia tidak lepas dari pengaruh perubahan global, perkembangan ilmu pengetahuan dan teknologi serta seni dan budaya. Selain itu reformasi kurikulum pendidikan yang sudah diadakan pembaharuan Ditinjau dari kurikulum 1975, 1984, 1994, 2004 (KBK), 2006 (KTSP), dan 2013 juga tidak membawa dampak positif terhadap perkembangan mutu di dunia pendidikan, sehingga sampai saat ini pun mutu pendidikan kita masih rendah. Peran pengembang kurikulum menjadi sangat penting bagi dunia pendidikan untuk pencapaian proses dan hasil belajar yang lebih baik.

Sistem dan mutu pendidikan di Indonesia masih tertinggal jauh dibanding negara-negara lain. Karena masih banyaknya masalah dalam dunia pendidikan yang di hadapi. Di lain pihak pemerintah sendiri tidak segera membenahi kondisi pendidikan yang ada di Indonesia. Disamping itu reformasi kurikulum pendidikan yang sudah diadakan pembaharuan juga kurang membawa dampak positif terhadap perkembangan mutu di dunia pendidikan, sehingga sampai saat ini pun mutu pendidikan di Indonesia masih rendah.

Adanya perubahan kurikulum pada dasarnya merupakan upaya untuk memperbaiki kurikulum terdahulu. Dalam kurikumlum yang baru tentunya terdapat hal-hal yang baru pula, sedangkan pada kurikulum yang lama tentunya ada alasan atau permasalahan yang menjadi latar belakang munculnya inovasi dalam pendidikan yang di dalamnya ada kurikulum sebagai sistem penggeraknya.

Namun jika dicermati, perubahan kurikulum yang dirasa menjadi suatu siklusyang ekstrem malah menunjukkan banyak masalah karena perubahan kurikulum itu sendiri yang terlalu sering. Setiap pergantian rezim kepemimpinan atau perubahan menteri pendidikan sendiri hampir bisa dipastikan akan terjadi perubahan kurikulum yang akhirnya membuat para aktor di bidang pendidikan tersesat di dalam kurikulum yang tidak jelas. Seharusnya perubahan kurikulum tidak boleh dilakukan secara radikal, ibaratnya pejabat berikutnya tinggal melanjutkan apa yang telah ditinggalkan oleh pendahulunya. Selain itu dengan adanya perubahan-perubahan kurikulum yang terjadi, semakin membingungkan penyelenggara pendidikan di lapangan, setalah diadakannya perubahan dan pengimplementasian dari kurikulum di bebeberapa sekolah, ternyata tidak semua sekolah memberi respon yang positif ada juga memberi respon negatif dan masalah itu 
muncul pada pengimplementasian dan teknis pelaksanaannya. Sehingga sekolah sebagai penyelenggara pendidikan formal sedikit banyaknya pada tahap awal membutuhkan energi yang besar hanya untuk mengetahui dan memahami isi dan tujuan kurikulum baru. Dalam teknis pelaksanaannya pun terkendala disebabkan perlunya adaptasi terhadap perubahan atas kurikulum terdahulu yang sudah biasa diterapkannya dan juga kataktrerisitk yang ada disetiap kurikulum pada masa Reformasi.

\section{METODE}

Penelitian ini merupakan penelitian kepustakaan (library research). Penelitian kepustakaan adalah penelitian yang dilakukan di perpustakaan atau museum terhadap bahan-bahan berupa buku-buku, majalah atau dokumen lainnya yang lainnya yang ada (Amar, 2007). Penelitian ini dikatakan sebuah penelitian kepustakaan karena pengumpulan datanya dilakukan dengan menghimpun data dari berbagai literature. Tujuan penelitian ini adalah untuk mengumpulkan data dan informasi dengan bantuan bermacam-macam material yang terdapat di ruang perpustakaan, seperti: buku-buku, majalah, dokumen dan catatan kisah-kisah sejarah dan lain-lainnya.

\section{PEMBAHASAN}

\section{Analisis Perkembangan Kurikulum Berbasis Kompetensi (kbk) 2004}

Pasca turunnya Soeharto dari tahta Presiden, sistim pemerintahan hanya fokus kepada masalah pemerintahan. Yang menyebabkan sektor lain seperti pendidikan kurang mendapat perhatian serius pada awal masa reformasi. Perubahan arah dan penulisan sejarah masa reformasi juga mempengaruhi materi pembelajaran dalam kurikulum yang dikembangkan kepada peserta didik. Salah satu keputusan yang menonjol para era reformasi adalah adanya otonomi daerah yang lebih luas.

Pengembangan kurikulum berbasis kompetensi merupakan amanat dari Undang-undang Nomor 20 Tahun 2003 tentang Sistem Pendidikan Nasional, sebagai dimana dimuat dalam penjelasan UU tersebut yang menyatakan: Strategi pembangunan pendidikan nasional ditempuh, antara lain melalui: (a) pelaksanaan pendidikan agama serta akhlak mulia, (b) pengembangan dan pelaksanaan kurikulum berbasis kompetensi dan, (c) proses pembelajaran yang mendidik dan dialogis. Namun demikian, perlu diketahui bahwasanya kurikulum berbasis kompetensi sudah mulai dikembangkan oleh pusat kurikulum (Soedijarto, 2010).

Pengembangan kurikulum berbasis kompetensi juga merupakan upaya penyempurnaan kurikulum sebelumnya (Kurikulum 1994). Kurikulum 1994 perlu disesuaikan dengan perubahan dan tuntutan jaman. Perkembangan dan perubahan secara terus menerus ini menuntut perlunya perbaikan sistem pendidikan nasional termaksud penyempurnaan kurikulum yang mampu bersaing dan menyesuaikan diri dengan perubahan zaman tersebut.

Berdasarkan alasan tersebut maka terjadi reformasi dibidang pendidikan yang salah satu hasilnya adalah di rancangnya kurikulum baru yakin kurikulum berbasis kompetensi oleh Departemen Pendidikan yang mulai diberlakukan pada tahun 2004. Kurikukum 2004 ini lebih dikenal dengan Kurikulum Berbasis Kompetensi (kbk). Pendidikan berbasis kompetensi menitik beratkan pada pengembangan kemampuan untuk melakukan tugas-tugas tertentu sesuai dengan standar performance yang telah ditetapkan.

Dan sebab gantinya kurikulum berbasis kompetensi ini dikarena perubahan zaman yang semakin hari semakin berubah. Sehingga dengan adanya perubahan kurikulum ini, berdampak pada kemajuan bangsa dan negara. Kurikulum pendidikan harus berubah tapi diiringi juga dengan perubahan dari seluruh masyarakat di Indonesia yang harus mengikuti perubahan tersebut

Prinsip-prinsip pengembangan kurikulum berbasis kompetensi

1) Keimanan, nilai, dan budi perkerti luhur

2) Penguatan integritas nasional yang dicapai melalui pendidikan

3) Keseimbangan etika, logika, estetika, dan kinestetika (Arifin, 2011).

a. Kelebihan dan kelemahan dari kurikulum berbasis kompetensi

1) Kelebihan KBK

a) Mengembangkan kompetensi-kompetensi siswa pada setiap aspek mata pelajaran dan bukan pada penekanan penguasaan konten mata pelajaran itu sendiri.

b) Mengembangkan pembelajaran yang berpusat pada siswa (Studen Oriented).

2) Kelemahan KBK

a) paradigma guru dalam pembelajaran KBK masih seperti kurikulum-kurikulum sebelumnya yang lebih pada teacher oriented.

b) Sarana dan prasarana pendukung pembelajaran yang belum merata setiap sekolah. 
b. Karakteristik kurikulum berbasis kompetensi

Depdiknas (2002) mengemukan karakteristik KBK secara lebih rinci sebagai berikut:

1) Menekankan kepada ketercapaian kompetensi siswa baik secara individual maupaun klasikal

2) Berorientasi pada hasil belajar dan keberagaman.

3) Penyampaian dalam pembelajaran menggunakan pendekatan dan metode yang bervariasi.

\section{Analisis Perkembangan Kurikulum Tingkat Satuan Pendidikan ( KTSP 2006)}

Dalam Standar Nasional Pendidik (SNP Pasal1, ayat 15) dikemukakan bahwa Kurikulum Tingkat Satuan Pendidikan (ktsp) adalah kurikulum operasional yang disusun dan dilaksanakan oleh masing-masing satuan pendidikan. Penyususnan ktsp dilakukan oleh satuan pendidikan dengan memperhatikan dan berdasarkan standar kompetensi dan kompetensi dasar yang dikembangkan oleh Badan Standar Nasional Pendidikan (BNSP).

KTSP resmi diberlakukan secara nasional dengan terbitnya PP No. 19/2005 dan Pemdiknas No. 24/2006. Pengembangan kurikulum tingkat satuan pendidikkan berpedoman pada standar kompetensi, Kompetensi Dasar, Standar isi dan Standar Kompetensi lulusan, yang digunakan sebagai acuan pembelajaran disekolah denganmenekankan pencapaian kemampuan minimal pada setiap tingkatan kelas dan pada akhirnya satuan pendidikan (Asri, 2017).

Alasan digantinya kurikulum tingkat satuan pendidikan (ktsp) dengan kurikulum baru yang akan mulai diterapkan tahun 2014. Banyak alasan kenapa terjadi perubahan kurikulum, disamping alasan kurikulum sebelumnya harus disempunakan kerena ada kekurangan disana-sini, tapi yang paling mendasar adalah agar kurikulum yang akan diterapkan tersebut mampu menjawab tantangan zaman yang akan terus berubah tanpa dapat dicegah, dan untuk mempersiapkan peserta didik yang mampu bersaing di masa depan dengan segala kemajuan ilmu pengetahuan dan teknologi.

a.. Prinsip-prinsip pengembangan kurikulum tingkat satuan pendidikan ( KTSP 2006)

1) Berpusat pada potensi, perkembangan, serta kebutuhan peserta didik dan lingkungannya. Pengembangan kurikulum didasarkan atas prinsip bahwa peserta didik adalah sentral proses pendidikan agar menjadi manusia yang bertakwa, berakhlak mulia, berilmu, serta warga negara yang demokratis sehingga perlu disesuaikan dengan potensi, perkembangan, kebutuhan, dan lingkungan siswa.

2) Beragam dan terpadu. Kurikulum dikembangkan dengan memperhatikan keragaman peserta didik, kondisi daerah dengan tidak membedakan agama, suku, budaya, adat, serta status sosial ekonomi dan gender. Kurikulum meliputi substansi komponen muatan wajib kurikulum, muatan lokal, dan pengembangan diri secara terpadu.

3) Tanggap terhadap perkembangan ilmu pengetahuan, teknologi, dan seni. Kurikulum dikembangkan atas kesadaran bahwa ilmu pengetahuan, teknologi, dan seni berkembang secara dinamis.

a.Kelebihan dan kekurangan KTSP 2006

1) Kelebihan KTSP

a) Mendorong terwujudnya otonomi sekolah dalam menyelenggarakan pendidikan.

b) Mendorong para guru, kepala sekolah, dan pihak manajemen sekolah untuk semakin meningkatkan kreativitasnya dalam penyelenggaraan program-program pendidikan.

c) KTSP memungkinkan bagi setiap sekolah untuk mengembangkan dan menitik beratkan pada mata pelajaran tertentu yang sesuai dengan kebutuhan peserta didik.

d) KTSP mengurangi beban belajar anak, sehingga lebih sederhana tetapi tetap memberi tekanan pada perkembangan siswa.

2) Kekurangan KTSP

a) Kurangnya SDM yang diharapkan mampu menjabarkan ktsp pada kebanyakan satuan pendidikan yang ada.

b) Kurangnya ketersediaan sarana dan prasarana pendukung sebagai kelengkapan dari pelaksanaan ktsp.

c) Masih banyak guru yang belum memahami ktsp secara Komprehensif baik konsepnya, penyusunan maupun prakteknya di lapangan.

b. Karakteristik Kurikulum Tingkat Satuan Pendidikan 2006

Menurut Sanjaya ada beberapa karakteristik KTSP:

1. Di lihat dari desainnya, ktsp adalah kurikulum berorientasi pada disiplin ilmu. Hal ini bisa dilihat dari struktur ktsp yang memuat sejumlah mata pelajaran yang harus dikuasai oleh peserta didik. 
2. KTSP adalah kurikulum berorientasi pada pengembangan individu. Di samping itu, dalam ktsp terdapat komponen pengembangan diri yang menekankan pada aspek pengembangan bakat dan minat siswa.

3. Ktsp adalah kurikulum yang mengakses kepentingan daerah yang sesuai dengan prinsip pengembangan kurikulum yang berpusat pada potensi, perkembangan, kebutuhan, dan kepentingan peserta didik dan lingkungannya (Thibatul, 2015).

\section{Analisis Perkembangan Kurikulum 2013}

Kurikulum 2013 merupakan kurikulum yang sedang dalam tahap perencanaan dan saat ini sedang dalam proses pelaksanaan oleh pemerintah, karena ini merupakan perubahan dari struktur kurikulum tingkat satuan pendidikan (ktsp). Kurikulum 2013 merupakan perangkat mata pelajaran dan program pendidikan berbasis sains yang diberikan oleh suatu lembaga penyelenggara pendidikan dengan tujuan untuk mempersiapkan lahirnya generasi emas bangsa Indonesia, dengan sistim dimana siswa lebih aktif dalam kegiatan belajar mengajar. Kurikulum 2013 ini bertujuan untuk mendorong peserta didik atau siswa agar lebih baik melakukan observasi, bertanya, bernalar, dan mempresentasikan apa yang mereka peroleh atau mereka ketahui setelah menerima materi pembelajaran (Fachrudin, 2018).

Inti dari Kurikulum 2013, adalah pada upaya penyederhanaan, dan tematik, integratif. Kurikulum 2013 disiapkan untuk mencetak generasi yang siap di dalam menghadapi masa depan. Karena itu kurikulum disusun untuk mengantisipasi perkembangan masa depan. Titik beratnya adalah mendorong peserta didik atau siswa, mampu lebih baik dalam melakukan observasi, bertanya, bernalar, dan mengkomunikasikan(mempresentasikan), apa yang mereka peroleh atau mereka ketahui setelah menerima materi pembelajaran.

1. Prinsip-prinsip pengembangan kurikulum 2013

Kemdikbud (2012) telah memberikan penejelasan mengenai prinsip-prinsip sebagai berikut:

a. Kurikulum satuan pendidikan atau jenjang pendidikan bukan merupakan daftar mata pelajaran.

b. Standar Kompetensi lulusan ditetapkan untuk satu satuan pendidikan, jenjang pendidikan, dan program pendidikan (Shobirin, 2016).

c. Model kurikulum berbasis kompetensi ditandai oleh pengembangan komptensi berupa sikap, pengetahuan, keterampilan berfikir, dan keterampilan psikomotorik yang dikemas dalam berbagai mata pelajaran.

d. Kurikulum dikembangkan dengan memberikan kesempatasan kepada peserta didik untuk mengambarkan perbedaan dalam kemampuan dan minat.

2 . Kelebihan dan kelemahan kurikulum 2013

a. Kelebihan K-13

Kurikulum 2013 menggunakan pendekatan yang bersifat alamiah (kontekstual) karena berfokus dan bermuara pada hakekat peserta didik untuk mengembangkan berbagai kompetensi sesuai dengan kompetensinya masing-masing. Dalam hal ini peserta didik merupakan subjek belajar dan proses belajar berlangsung secara alamiah dalam bentuk bekerja dan mengalami berdasarkan kompetensi tertentu, bukan transfer pengetahuan.

b. Kekurangan Kurikulum 2013

Pemerintah seolah melihat semua guru dan siswa memiliki kapasitas yang sama dalam kurikulum 2013. Guru juga tidak pernah dilibatkan langsung dalam proses pengembangan kurikulum 2013.

\section{3..Karakteristik K-13}

Kurikulum 2013 dikembangkan dengan karakteristik sebagai berikut (Kemendikbud, 2013):

a. Mengembangakan sikap spiritual dan sosial, rasa ingin tahu, Kreativitas, kerja sama dengan kemampuan intelektual dan psikomotorik secara simbang.

b. Memberikan pengalaman belajar terencana ketika peserta didik menerapkan apa yang dipelajari di sekolah ke masyarakat dan memanfaatkan masyarakat sebagai sumber belajar secara seimbang. 
Tabel 1. Perbandingan antara KBK, KTSP dan K-13

\begin{tabular}{|c|c|c|}
\hline KBK & KTSP & K-13 \\
\hline $\begin{array}{l}\text { Mengembangkan kompetensi- } \\
\text { kompetensi siswa pada setiap } \\
\text { aspek mata pelajaran dan } \\
\text { bukan pada penekanan } \\
\text { penguasaan konten mata } \\
\text { pelajaran itu sendiri. }\end{array}$ & $\begin{array}{l}\text { Mendorong terwujudnya otonomi } \\
\text { sekolah dalam menyelenggarakan } \\
\text { pendidikan. }\end{array}$ & $\begin{array}{l}\text { Kurikulum } 2013 \text { menggunakan } \\
\text { pendekatan yang bersifat alamiah } \\
\text { (kontekstual) karena berfokus } \\
\text { dan bermuara pada hakekat } \\
\text { peserta didik untuk } \\
\text { mengembangkan berbagai } \\
\text { kompetensi sesuai dengan } \\
\text { kompetensinya masing-masing. } \\
\text { Lebih menekankan kepada } \\
\text { pendidikan karakter. }\end{array}$ \\
\hline $\begin{array}{l}\text { Mengembangkan } \\
\text { pembelajaran yang berpusat } \\
\text { pada siswa (Studen Oriented). } \\
\text { Guru cenderung kurang } \\
\text { kreatif. }\end{array}$ & $\begin{array}{l}\text { Mendorong para guru, kepala } \\
\text { sekolah, dan pihak manajemen } \\
\text { sekolah untuk semakin } \\
\text { meningkatkan kreativitasnya dalam } \\
\text { penyelenggaraan program-program } \\
\text { pendidikan. }\end{array}$ & $\begin{array}{l}\text { Guru cenderung kurang kreatif } \\
\text { dalam proses pembelajaran. Di } \\
\text { karenakan peserta didik lebih } \\
\text { aktif dari pada guru. }\end{array}$ \\
\hline $\begin{array}{l}\text { Guru menjabarkan kurikulum } \\
\text { yang dibuat Depdiknas } \\
\text { Siswa dapat bergerak aktif } \\
\text { secara fisik ketika belajar } \\
\text { dengan memanfaatkan panca } \\
\text { indra seoptimal mungkin dan } \\
\text { membuat saluran tubuh serta } \\
\text { pikiran terlibat dalam proses } \\
\text { pembelajara. }\end{array}$ & $\begin{array}{l}\text { Guru membuat kurikulum sendiri } \\
\text { KTSP mengurangi beban belajar } \\
\text { anak, sehingga lebih sederhana } \\
\text { tetapi tetap memberi tekanan pada } \\
\text { perkembangan siswa. }\end{array}$ & $\begin{array}{l}\text { Guru menjabarkan kurikulum } \\
\text { yang dibuat Kemdikbud, } 2013 . \\
\text { Asumsi dari kurikulum } 2013 \\
\text { adalah tidak ada perbedaan } \\
\text { antara anak desa atau kota. } \\
\text { Seringkali anak di desa } \\
\text { cenderung tidak diberi } \\
\text { kesempatan untuk } \\
\text { memaksimalkan potensi mereka }\end{array}$ \\
\hline
\end{tabular}

\section{SIMPULAN}

Kurikulum Berbasis Kompetensi adalah suatu konsep kurikulum yang menekankan pada pengembangan dan penguasaan kompetensi bagi peserta didik melalui berbagai kegiatan dan pengalaman. Sistem pembelajaran dalam kbk jika dilihat karakteristik khusus bahwa sistem pembelajaran dalam kbk sangatlah praktis untuk pengembangan peserta didik, dalam arti dengan sistem ini sifatnya universal yang telah mencakup secara keseluruhan kegiatan pembelajaran yang menjadi kebutuhan p okok peserta didik. Secara jelas, peranan tenaga pengajar dalam sistem penyajian modul hanya merupakan sumber tambahan dan pembimbing yang membimbing peserta didik, namun tidak menutup kemungkinan peserta didik membutuhkan arahan dan pembinaan tenaga pengajar secara intensif, dalam rangka mencapai tujuan pendidikan profesional.

Kurikulum tingkat satuan pendidikan (ktsp) merupakan salah satu bentuk realisasi kebijakan desentralisasi di bidang pendidikan agar kurikulum benar-benar sesuai dengan kebutuhan pengembangan potensi peserta didik di sekolah yang bersangkutan di masa sekarang dan yang akan datang dengan mempertimbangkan kepentingan lokal, nasional dan tuntutan global dengan semangat manajemen berbasis sekolah (MBS). Kurikulum Tingkat Satauan Pendidikan adalah kurikulum operasional yang disusun dan dilaksanakan masing-masing satuan pendidikan/sekolah. Di samping itu, karakteristik Kurikulum Tingkat Satuan Pendidikan adalah kurikulum yang berorientasi pada pengembangan individu, yang mana hal ini dapat dilihat dari adanya standar kompetensi dasar yang dijabarkan oleh indikator. Dalam ktsp terdapat komponen pengembangan diri yang menekankan pada aspek pengembangan bakat dan minat siswa.

Kurikulum 2013 ini adalah sebuah kurikulum yang dikembangkan untuk meningkatkan dan menyeimbangkan kemampuan soft skiils dan hard skiils yang berupa sikap, pengetahuan, dan keterampilan. Dari kurikulum berbasis kompetensi 2004, kurikulum tingkat satuan pendidikan 2006, dan Kurikulum-13 didapatkan bahwasanya K-13 lebih efesian untuk meningkatkan mutu belajar pembelajaran peserta didik. Namun Kurikulum 13 ini yaitu peningkatan efektifitas pembelajaran pada satuan pendidikan dan penambahan waktu pembelajaran di sekolah. Pada K-13 peserta didik banyak mencari tau dengan menggunakan teknologi saat ini. 


\section{REFERENSI}

Amar, R. (2007). Pengantar Metodologi Penelitian. Padang: Hayfa Press.

Arifin, Z. (2011). Konsep Dan Model Pengembangan Kurikulum. Bandung: Remaja Rosdakarya.

Asri, M. (2017). Dinamika Kurikulum di Indonesia,. MODELING: Jurnal Program Studi PGMI 4(2).

Fachrudin, W. Y. (2018). Implementasi Kurikulum 2013 (K.13) Pada Mata Pelajaran Pendidikan Agama Islam Sekolah Dasar (SD). Jurnal Pendidikan Islam, Universitas Yudharta Pasuruan, 3(2).

Hakim, D. (2014). Implementasi Pendidikan Budaya dan Karakter Bangsa dalam Kurikulum Tingkat Satuan Pendidikan (KTSP) di Sekolah. Religi: Jurnal Studi Islam, 5(2), 145-168.

Kemendikbud. (2013). Kompetensi Dasar (Kurikulum Sekolah Menengah Pertama 2013). Jakarta: Kemendikbud.

Muhammedi. (2016). Perubahan Kurikulum di Indonesia : Studi Kritis Tentang Upaya Menemukan Kurikulum Pendidikan Islam yang Idea. 4(1).

Sanjaya, W. (2008). Strategi Pembelajaran Berorientasi Standar Proses Pendidikan. Jakarta: Kencana Prenada Medika Grup.

Shobirin, M. a. (2016). Konsep dan Implementasi Kurikulum 2013 di Sekolah Dasar. Yogyakarta: Deepublish.

Soedijarto, D. (2010). Sejarah Pusat kurikulum, Pusat Kurikulum Badan Penelitian dan Pengembangan Kemerdekaan Pendidikan Nasional.

Soemanto, \& Soetopo. (1991). Pembinaan dan Pengembangan Kurikulum Sebagai Substansi Problem Administrasi Pendidikan. . Jakarta: Bumi Aksara.

Thibatul, N. H. M. (2015). Pengaruh Perubahan Kuikulum 2013 Ke Kurikulum 2006 (KTSP) Terhadap Proses Pembelajaran (Studi Kasus DI SMP Negeri 1 Kepung). 1 (2). 